De la ROSA-RODRÍGUEZ, R; LARA-HERRERA, A; TREJO-TÉLLEZ, LI; PADILLA-BERNAL, LE; SOLIS-SÁNCHEZ, LO; ORTIZ-RODRÍGUEZ, JM. 2020. Water and fertilizers use efficiency in two hydroponic systems for tomato production. Horticultura Brasileira 38: 47-52. DOI - http://dx.doi. org/10.1590/S0102-053620200107

\title{
Water and fertilizers use efficiency in two hydroponic systems for tomato production
}

\author{
Rodolfo De la Rosa-Rodríguez ${ }^{1 \mathbb{D}}$; Alfredo Lara-Herrera ${ }^{2 * \mathbb{D} ;}$; Libia Iris Trejo-Téllez ${ }^{3 \mathbb{D}}$; Luz Evelia Padilla- \\ Bernal ${ }^{4} \mathbb{D}$; Luis Octavio Solis-Sánchez ${ }^{1} \mathbb{D}$; José Manuel Ortiz-Rodríguez ${ }^{1 \mathbb{D}}$
}

${ }^{1}$ Unidad Académica de Ingeniería Eléctrica, Universidad Autónoma de Zacatecas (UAZ), Zacatecas, México; méxico.rodox116@hotmail. com;1_solis@ymail.com; morvymm@yahoo.com.mx; ${ }^{2}$ Unidad Académica de Agronomía (UAZ), Zacatecas, México; alara204@hotmail. com; ${ }^{3}$ Colegio de Postgraduados, Montecillo, México; méxico.tlibia@colpos.mx; ${ }^{4}$ Unidad Académica de Contaduría y Administración (UAZ), Zacatecas; méxico.luze@uaz.edu.mx, (*author for correspondence)

\begin{abstract}
The amount of water and fertilizers used in the production of vegetables, specifically tomatoes, is high. This study was carried out to determine water and fertilizers use efficiency in closed and open hydroponic systems for tomato production under greenhouse conditions. Two treatments with eight replications were assessed; each replication consisted of 67 pots with two plants each. One treatment was a closed hydroponic system (with nutrient solution recirculation), and the other was an open hydroponic system (with non-recirculating nutrient solution). We quantified the amounts of water and fertilizers applied, as well as the losses (drained nutrient solution), in the two treatments during the entire cycle of tomato. In the nutrient solution (NS) we also measured electric conductivity (EC), $\mathrm{pH}$, volume applied, and volume drained, and total weight of fruits ( 25 pickings). There were no significant differences between the two treatments on fruit production. Water use efficiency was 59.53 $\mathrm{kg} /$ fruit $/ \mathrm{m}^{3}$ for the closed system and $46.03 \mathrm{~kg} /$ fruit $/ \mathrm{m}^{3}$ in the open system. In comparison to the open system, the closed system produced $13.50 \mathrm{~kg}$ more fruit per cubic meter of water, while 10.31 grams less fertilizers per kilogram of fruit produced were only applied. Water and fertilizers use efficiency were higher in the closed system, by $22.68 \%$ and $22.69 \%$, respectively. More efficiency was obtained in the closed system, regarding the open system. We concluded that the closed system is a good alternative to produce tomato and preserve the resources involved in the process (like water and fertilizers), thus reducing pollution.
\end{abstract}

Keywords: Solanum lycopersicum, efficient water and fertilizers use, open and closed hydroponics systems, recirculation.

\section{RESUMO}

Eficiência no uso de água e fertilizantes em dois sistemas hidropônicos para produção de tomate

A quantidade de água e fertilizantes usados na produção de vegetais, especificamente tomate, é alta. Este estudo foi realizado para determinar a eficiência do uso de água e fertilizantes em sistemas hidropônicos fechados e abertos para produção de tomate em casa de vegetação. Dois tratamentos com oito repetições foram avaliados; cada repetição consistiu de 67 vasos com duas plantas cada. Um tratamento foi um sistema hidropônico fechado (com recirculação de solução nutritiva) e o outro foi um sistema hidropônico aberto (com solução nutritiva não recirculante). Foram quantificadas as quantidades de água e fertilizantes aplicados, bem como as perdas (solução nutritiva drenada), nos dois tratamentos durante todo o ciclo do tomate. Na solução nutritiva (NS) também foram medidos a condutividade elétrica $(\mathrm{CE}), \mathrm{pH}$, volume aplicado e volume drenado, e peso total de frutas ( 25 coletas). Não houve diferenças significativas entre os dois tratamentos na produção de frutos. A eficiência no uso da água foi de $59,53 \mathrm{~kg} /$ fruto $/ \mathrm{m}^{3}$ no sistema fechado e $46,03 \mathrm{~kg} /$ fruto/ $\mathrm{m}^{3}$ no sistema aberto. Em comparação com o sistema aberto, o sistema fechado produziu $13,50 \mathrm{~kg}$ a mais de frutos por $\mathrm{m}$ cubico de água, enquanto apenas 10,31 gramas a menos de fertilizante por quilograma de frutas produzidas foram aplicados. A eficiência no uso de água e fertilizantes foi maior no sistema fechado em $22,68 \%$ e $22,69 \%$, respectivamente. Mais eficiência foi obtida no sistema fechado, em relação ao sistema aberto. Conclui-se que o sistema fechado é uma boa alternativa para a produção de tomate e preservar os recursos envolvidos no processo (como água e fertilizantes), reduzindo a poluição.

Palavras-chave: Solanum lycopersicum, uso eficiente de água e fertilizantes, sistemas de hidroponia abertos e fechados, recirculação.

\section{Received on March 11, 2019; accepted on November 6, 2019}

$\mathrm{T}$ oday's climate change and scarcity of good quality water are becoming increasingly severe worldwide (De Wrachien \& Goli, 2015). Both of them are issues that demand changes in agriculture. Particularly important are irrigation systems that can maximize water savings and rational water use; as well as production yields with the most efficient management possible to maintain food safety and at the same time preserve natural resources (Flores et al., 2007, Grewal et al., 2011).

It is possible to have a higher efficient use of water in a greenhouse because there is a better control of environmental conditions for crop production (Costa et al., 2018), including tomato as one 
of the most cultivated vegetables due to its profitability and its consumption (Krause et al., 2017).

Greenhouse hydroponics is a technique that produces the largest volumes of tomato per unit of area, thus resulting in a greater productivity (Magaña-Lira et al., 2013).

Hydroponics is a technique used to grow plants in a combination of water and nutrients called nutrient solution (NS). This technology may have mechanical support for the plant, generally an artificial medium (substrate) that provides appropriate physical and chemical characteristics for plants (Steiner 1984; Krause et al., 2017). The use of hydroponics to produce vegetables in greenhouses is highly efficient in water use since losses due to evaporation and percolation are lower (Grewal et al., 2011, López et al., 2011).

Hydroponic systems using substrates are known as open when the excess NS drains into the soil and infiltrates, often reaching ground water. In general, the NS is not recovered. These systems have the disadvantage of requiring high inputs of water and fertilizers, as well as causing negative impacts on the environment (Kempen et al., 2016). In contrast, closed hydroponic systems have the important advantage of re-using the NS after it is drained from the substrate. Thus, losses due to infiltration in soil and groundwater pollution are prevented (Komosa et al., 2011). Besides the environmental benefits, closed hydroponic systems can provide higher economic profits, since they reduce the quantity of water and fertilizers used during production (Pardossi et al., 2011, Sánchez-Del Castillo et al., 2014, Moreno-Pérez et al., 2015).

Closed hydroponic systems are more efficient in using water and nutrients than open systems (Komosa et al., 2011). However, one aspect that limits the reuse of the NS and, thus water and nutrient use efficiency, is the accumulation of salts that can cause imbalances and antagonism among plant nutrients (Herrero et al., 2014; Kempen et al., 2016), as well as the risk of spreading phytopathogens (Sánchez-
Del Castillo et al., 2014). However, De la Rosa-Rodríguez et al. (2017) reported that, in an eight months tomato cycle in a closed hydroponic system, no phytopathogenic microorganisms were developed, which allows an important saving of water and nutrients when reusing the NS.

Climate change and the increasing human population worldwide challenge sustainable growth and food security. Hence, there is a dire need to save water and fertilizers and to maintain or increase food production. To satisfy that need, basic and technical questions must be answered, and novel information has to be generated. Thus, this study was carried out in order to determine the use efficiency of water and fertilizers applied in a closed hydroponic system and compare it with an open system during a tomato production cycle.

\section{MATERIAL AND METHODS}

\section{Location of the experiment and interior greenhouse conditions}

This study was performed in a 640 $\mathrm{m}^{2}$ multi-tunnel greenhouse with passive control weather. The greenhouse was located at the Autonomous University of Zacatecas, Mexico (22 $43^{\prime} 42^{\prime}$ N, $\left.102^{\circ} 40 ' 58^{\prime} \mathrm{W}\right)$. Temperature and relative humidity inside the greenhouse were measured with four Watchdog $\mathbb{}$ sensors located in each greenhouse tunnel. The information was collected every $15 \mathrm{~min}$ during the experiment, from March 21, 2017 to November 4, 2017. Mean temperature inside the greenhouse during the entire cycle was $24.7^{\circ} \mathrm{C}$; average high temperature was $33.3^{\circ} \mathrm{C}$ and the average low was $17.3^{\circ} \mathrm{C}$. Mean relative humidity was $53.2 \%$.

Genetic material and substrate

Seeds of saladette type tomato (Solanum lycopersicum) cultivar "El Cid" of indeterminate growth habit were acquired from the Harris Moran Seed Company. Seeds were sown in trays with 25 mL wells on February 15, 2017. Thirty-five days after sowing, seedlings were transplanted to $20 \mathrm{~L}$ pots, with two plants per pot. The used substrate was fine perlite whose characteristics were: bulk density $0.18 \mathrm{~g} \mathrm{~cm}^{-3}, 27 \%$ aeration porosity, 37\% water retention capacity and $60 \%$ total porosity.

\section{Experimental design and units}

To evaluate water use efficiency and fertilizers consumption, two treatments were established in a randomized complete block design. Each treatment consisted of eight replications, each replication having 67 pots with two plants each, reaching 134 plants. This arrangement gave a total of 16 rows that had a length of $16 \mathrm{~m}$ and a width of 2.5 $\mathrm{m}$, and each row was considered as an experimental unit.

Drained NS was conducted from pots with $20 \mathrm{~L}$ fine perlite substrate to a $200 \mathrm{~L}$ capacity reservoir. In the reservoir, after its collection, the NS was restored in terms of $\mathrm{EC}, \mathrm{pH}$ and nitrate concentration, by adding water to decrease EC, a solution of $\mathrm{H}_{2} \mathrm{SO}_{4} 1 \mathrm{~N}$ to regulate $\mathrm{pH}$ to 5.5-6.5 and a solution of $\mathrm{KNO}_{3} 1 \mathrm{~N}$ to reach an EC of 2.0-2.5 $\mathrm{dS} \mathrm{m} \mathrm{m}^{-1}$. This last solution was applied in order to recover the ions that the tomato plant absorbs in hydroponic conditions (Lewis \& Marmoy, 1940; Kempen et al., 2016). When the NS was restored, it was recirculated in the closed system. In the case of the open system, the NS was collected in a reservoir of the same capacity. It was then restored and used out of greenhouse (Figure 1).

Nutrient solution management during the experiment

During the productive cycle, the Steiner NS was used in the irrigation system. The drained NS of each treatment was stored in the respective reservoir.

The water used to prepare the NS had a $\mathrm{pH}$ of 7.23 and an EC of $0.55 \mathrm{dS}$ $\mathrm{m}^{-1}$. The concentration of soluble ions in mol $\mathrm{m}^{-3}$ in the NS was as follows: $\mathrm{NO}_{3}=$ $0.21, \mathrm{P}_{-} \mathrm{PO}_{4}^{-}=0.02, \mathrm{SO}_{4}{ }^{2-}=0.70, \mathrm{HCO}_{3}{ }^{-}$ $=3.60, \mathrm{Cl}^{-}=0.80, \mathrm{Ca}^{2+}=1.85, \mathrm{Mg}^{2+}=$ $1.48, \mathrm{~K}^{+}=0.26, \mathrm{Na}^{+}=2.09$; in $\mathrm{mg} \mathrm{L}^{-1}$, concentrations of micronutrients were $\mathrm{Fe}=0.03, \mathrm{Mn}=0.02, \mathrm{Zn}=0.01, \mathrm{Cu}=0.00$ and $\mathrm{B}=0.10$. The fertilizers used were $\mathrm{Ca}\left(\mathrm{NO}_{3}\right)_{2} \cdot 0.2 \mathrm{NH}_{4} \mathrm{NO}_{3} \cdot \mathrm{H}_{2} \mathrm{O}, \mathrm{KNO}_{3}$, $\mathrm{K}_{2} \mathrm{SO}_{4}, \mathrm{MgSO}_{4} .7 \mathrm{H}_{2} \mathrm{O}, \mathrm{KH}_{2} \mathrm{PO}_{4}, \mathrm{H}_{3} \mathrm{PO}_{4}$, $\mathrm{H}_{2} \mathrm{SO}_{4}$. To supply the micronutrients, a fertilizer containing concentrations of Fe 6.6\%, Mn 2.6\%, Zn 1.1\%, B 0.9\%, $\mathrm{Cu} 0.3 \%$, and Mo $0.2 \%$ was used. Fe, 
$\mathrm{Mn}, \mathrm{Zn}$ and $\mathrm{Cu}$ were in their chelated form with EDTA. Of this fertilizer, 30 $\mathrm{g} \mathrm{m}^{-3}$ were applied to the NS. The water used came directly from a deep well and was negative for bacteria and fungi.

Management of the nutrient solution

The $\mathrm{pH}$ and $\mathrm{EC}$ were measured with a potentiometer and conductivity meter combo (Hanna Combo HI98130) in both the NS applied and the drained NS to regulate acidity and concentration of nutrients. Thus, an adequate balance of nutrients as well as optimal chemical conditions in the NS were kept.

\section{Measured variables}

\section{Water productivity}

To determine the water use efficiency, the relationship between the production (weight) of fruits obtained in kilograms during the entire cycle in both the open and the closed hydroponics systems was obtained, as well as the amount of water applied during the entire cycle in $\mathrm{m}^{-3}$. To calculate these values we used the formula:

Water use ef ficiency $=\frac{\text { Kilograms of fruits }}{\text { Cubic meters applied }}$

\section{Fertilizer quantity and productivity}

The fertilizers used during the entire crop cycle were quantified by weighting each fertilizer source used to prepare the NS. These weights were recorded during the eight months of the crop cycle in order to determine the quantity of fertilizers applied and its use efficiency, in relation to the yield obtained.

\section{Volume of applied solution}

The NS was applied through an automatic fertigation system. Scheduling of time and duration of irrigation was in function of the developmental stage and the environmental conditions inside the greenhouse. During the production stage, on average, 30-35 irrigations of three to four minutes for each day were applied. In each pot with two plants, two emitters $\left(2 \mathrm{~L} \mathrm{~h}^{-1}\right)$ were installed. A sample of the NS was taken from an emitter in each replication. Thus, a daily sample was collected of all the irrigation applications in a day to determine $\mathrm{EC}, \mathrm{pH}$ and quantity of applied NS. The amount of water to be applied was calculated based on the crop evapotranspiration (ETc), and this data was obtained following the methodology used by Kuşçu et al. (2014).

\section{Volume of collected solution}

The NS drained from each pot was conveyed along each row of pots to a plastic $18 \mathrm{~L}$ capacity container; an automatic system pumped it to a 200 $\mathrm{L}$ tank where EC, $\mathrm{pH}$ and quantity of solution collected were determined. The NS was then restored for recirculation (closed system treatment) or for use in another crop (open system treatment). The containers of the drained NS were placed at the end of each of the 16 rows of pots.

\section{Drainage percentage}

Drainage percentage was obtained in both systems based on the ratio of volumes of drained NS to applied NS, according to the following formula:

Drainage percentage $=\frac{\text { NS drained }}{\text { NS applied }} \times 100$

Both systems had the same volume applied but in closed system, the NS was recycled, while in the open system it was scrapped.

Yield

Yield was measured based on 25 tomato pickings during the crop cycle (March to November).

Every five days, from June 17, 2017 the fruits produced by each experimental unit were weighed and graded by weight levels, using the following scale: first grade $(>130 \mathrm{~g})$, second (100-130 g), third (60-99.99 g) and fourth (less than $60 \mathrm{~g}$ ). Fruits were picked based on visual maturity (color) known as "pink" (with 30 to $60 \%$ of the fruit surface red); this is the most important factor to determine the degree of maturity. At this stage of maturity (pink), the fruit has developed its main organoleptic characteristics (Casierra-Posada \& Aguilar-Avendaño, 2008).

Experimental design and statistical analysis

To test our treatments, we used a randomized complete block design with two treatments and eight replications. The results for the evaluated variables were subjected to an analysis of variance and means were compared using the Tukey test $(p \leq 0.05)$. Statistical analyzes were performed using the software Statistical Analysis System (SAS) version 9.4

\section{RESULTS AND DISCUSSION}

\section{Applied volume of nutrient solution}

Water use efficiency expressed in kilograms of fruits per cubic meter of water was higher in the closed system as compared to the open system (Table 1). Indeed, the closed hydroponic system produced $13.5 \mathrm{~kg}$ more fruit per cubic meter of water than the open system. Consequently, the tomato production we reached was $59.53 \mathrm{~g} \mathrm{~L}^{-1}$ in the

Table 1. Water and fertilizers use efficiency, relative to the quantities applied and drained in open and closed hydroponic systems during the crop cycle. Mexico, Academic Unit of Agronomy, Autonomous University of Zacatecas, 2017.

\begin{tabular}{|c|c|c|c|c|c|c|}
\hline Treatments & $\begin{array}{c}\text { Fertilizers } \\
\text { applied } \\
\left(\text { kg cycle }^{-1}\right)\end{array}$ & $\begin{array}{c}\text { Fertilizers } \\
\text { drained } \\
\left(\text { kg cycle }^{-1}\right)\end{array}$ & $\begin{array}{c}\text { NS } \\
\text { applied } \\
\left(\mathrm{m}^{3} \text { cycle }^{-1}\right)\end{array}$ & $\begin{array}{c}\text { NS discarded in } \\
\text { drainage } \\
\left(\mathrm{m}^{3} \mathrm{cycle}^{-1}\right)\end{array}$ & $\begin{array}{c}\text { Water use } \\
\text { efficiency } \\
\left(\mathbf{k g ~ m}^{-3}\right)\end{array}$ & $\begin{array}{c}\text { Fertilizers use } \\
\text { efficiency } \\
\left(\mathbf{g ~ k g}^{-1}\right)\end{array}$ \\
\hline Closed system & $440.78 \mathrm{~b}^{\mathrm{P}}$ & $1.88 \mathrm{~b}$ & $210.7 \mathrm{~b}$ & $0.9 \mathrm{~b}$ & $59.53 \mathrm{a}$ & $35.13 b$ \\
\hline Open system & $605.00 \mathrm{a}$ & $164.22 \mathrm{a}$ & $289.2 \mathrm{a}$ & $78.5 \mathrm{a}$ & $46.03 \mathrm{~b}$ & $45.44 \mathrm{a}$ \\
\hline
\end{tabular}

Water use efficiency is expressed in kilograms of fruits produced per cubic meter of water applied. *Fertilizers use efficiency is expressed in grams of applied fertilizer per kilogram of fruit produced. PValues in a column followed by the same letter are statistically equal (Tukey, $\mathrm{p} \leq 0.05)$. NS $=$ nutrient solution. 
closed hydroponic system and 46.03 $\mathrm{g} \mathrm{L}^{-1}$ in the open system. The closed system produced $26.9 \%$ more fruit per liter of water than the open system. In hydroponic culture systems with recirculation of NS under automatized greenhouse conditions, it is possible to obtain up to $67 \mathrm{~kg}$ fruit per cubic meter of water, and up to $45 \mathrm{~kg}$ in a system with non-recirculating nutrient solution (Stanghellini et al., 2003).

\section{Drained percentage}

The percentage of drained NS (\%D) varied from 25 to $34 \%$ in both systems (Table 2). This quantity of NS was reused in the closed system and eliminated only three times:1) during the initial stage of fruit formation; 2) in full production stage; and 3) at the end of the crop cycle. Together, this accounted for only $0.31 \%$ of the applied NS. In contrast, in the open system, all the drained solution was lost. When the plants had higher requirements of water, the drained quantity decreased in the first months of the crop (Table 2 ). Therefore, it is necessary to modify the irrigation schedule (mainly time and frequency) to satisfy the water demand, but without excessive drainage (ElMageed \& Semida, 2015).

At the end of the crop cycle in the open system, 78,500 L of water were lost as the solution discarded in drainage, which represents $98.8 \%$ more than the closed system that lost only $900 \mathrm{~L}$ as discarded solution in drainage during the entire crop cycle (Table 1).

\section{Nutrient and fertilizers quantities and use efficiency}

The total average quantity of fertilizers per month applied during the crop cycle (April-November) varied from $11.04 \mathrm{~kg}$ to $105.1 \mathrm{~kg}$, in the months of lowest and highest application, respectively. In the open system, we applied $164.22 \mathrm{~kg}$ of fertilizers more than in the closed system. In addition, in the closed system the amount of fertilizers decreased in $27.14 \%$ during tomato crop cycle, in comparison to the open system (Table 1). This was because of the recirculation of the NS. The use efficiency of the fertilizers was higher in the closed system, with $22.6 \%$ more efficiency as compared to the open

Table 2. Nutrient solution applied, drained and percentage drained on a typical day of each month of the tomato crop cycle grown in two hydroponic systems: open and closed. Mexico, Academic Unit of Agronomy, Autonomous University of Zacatecas, 2017.

\begin{tabular}{lccc}
\hline $\begin{array}{l}\text { Month of the } \\
\text { crop cycle }\end{array}$ & $\begin{array}{c}\text { Volume applied } \\
\text { per plant (mL) }\end{array}$ & $\begin{array}{c}\text { Volume collected } \\
\text { per row (L) }\end{array}$ & $\begin{array}{c}\text { Percentage } \\
\text { drained (\%) }\end{array}$ \\
\hline April & 432.84 & 9.28 & 32 \\
May & 873.16 & 18.13 & 31 \\
June & 2460.32 & 41.21 & 25 \\
July & 2970.08 & 51.73 & 26 \\
August & 3147.86 & 56.94 & 27 \\
September & 3050.12 & 59.26 & 29 \\
October & 2587.23 & 53.73 & 31 \\
November & 2390.75 & 54.46 & 34 \\
\hline
\end{tabular}

Table 3. Percentage of tomato fruits sorted into four weight grades and fruit yield by effect of two hydroponic systems, closed and open, in a crop cycle from March to November ( $\mathrm{n}=$ 8). Mexico, Academic Unit of Agronomy, Autonomous University of Zacatecas, 2017.

\begin{tabular}{|c|c|c|c|c|c|}
\hline \multirow{2}{*}{ Treatment } & \multicolumn{4}{|c|}{ Fruits in four quality grades (\%) } & \multirow{2}{*}{$\begin{array}{c}\text { Yield } \\
\left(\mathrm{kg} \mathrm{m}^{-2}\right)\end{array}$} \\
\hline & $\mathbf{1}^{\dagger}$ & 2 & 3 & 4 & \\
\hline Closed system & $38 \mathrm{a}^{\ddagger}$ & $47 \mathrm{a}$ & $10 \mathrm{a}$ & 4 a & $19.6 \mathrm{a}$ \\
\hline Open system & $40 \mathrm{a}$ & $46 \mathrm{a}$ & $11 \mathrm{a}$ & $4 \mathrm{a}$ & $20.8 \mathrm{a}$ \\
\hline
\end{tabular}

$\mathbf{1}^{\text {st }}$ grade (>130 g per fruit); $\mathbf{2}^{\text {nd }}$ grade (100-130 g per fruit); $\mathbf{3}^{\text {th }}$ grade (60-99.99 g per fruit); $4^{\text {th }}$ grade $(<60 \mathrm{~g}$ per fruit). Values in a column followed by the same letter are statistically equal (Tukey, $\mathrm{p} \leq 0.05$ ). system (Table 1). The nutrient quantities applied per $\mathrm{kg}$ of fruit were 16.09 and $20.81 \mathrm{~g}$ for the closed and open systems, respectively. These quantities were obtained considering $\mathrm{N}, \mathrm{P}, \mathrm{K}, \mathrm{Ca}$ and $\mathrm{Mg}$. Higher quantities of fertilizers were reported by Ojodeagua et al. (2008), who found $27.8 \mathrm{~g}$ nutrients (consider $\mathrm{N}$, $\mathrm{P}_{2} \mathrm{O}_{5}, \mathrm{~K}_{2} \mathrm{O}, \mathrm{Ca}$, and $\mathrm{Mg}$ ) per kilogram of fruit produced.

The quantities of nutrients (in grams) per cubic meter of NS in both systems were: $\mathrm{N}=175.9, \mathrm{P}=54.8, \mathrm{~K}=267.1, \mathrm{Ca}=$ 171.0, $\mathrm{Mg}=82.1$ and $\mathrm{S}=207.3$. Thus, they represented approximately $45.8 \%$ of the applied fertilizers. Nutrient uptake by the plants is affected by several factors, such as ionic concentration in the NS, the selectivity of the roots, climate and plant development stage (López et al., 2011). The uptake of nutrients is affected by the balance existing among them, which in closed systems is the main factor to maintain an optimal plant nutrition (Kempen et al., 2016).

For each $\mathrm{kg}$ of fertilizers, $28.45 \mathrm{~kg}$ of fruits were produced in the closed system, while in the open system, production was 22.00 kilogram of fruits per kilogram of fertilizers. In the closed system, $6.45 \mathrm{~kg}$ more fruits were produced as compared to the open system. These results are due to the recirculation of the NS since this allows reducing the water and fertilizers used (Pardossi et al., 2011, Sánchez-Del Castillo et al., 2014, Moreno-Pérez et al., 2015, Kempen et al., 2016).

\section{Yield}

The mean fruit yield was $20.2 \mathrm{~kg} \mathrm{~m}^{-2}$. There were no differences by effect of the evaluated treatments (Table 3), nor there was a difference in the categories measured in the weight of the harvested fruits. Nevertheless, the yield was achieved with greater productivity in the use of water and nutrients with recirculation of NS in the closed system. With this practice, we can reduce water consumption up to $33 \%$, N use in 59\%, $\mathrm{P}$ applications in $25 \%$, and $\mathrm{K}$ use in $55 \%$ as compared to the open system, with the possibility of obtaining higher yield with lower production costs and less pollution (Grewal et al., 2011).

Importantly, our results were $29 \%$ 


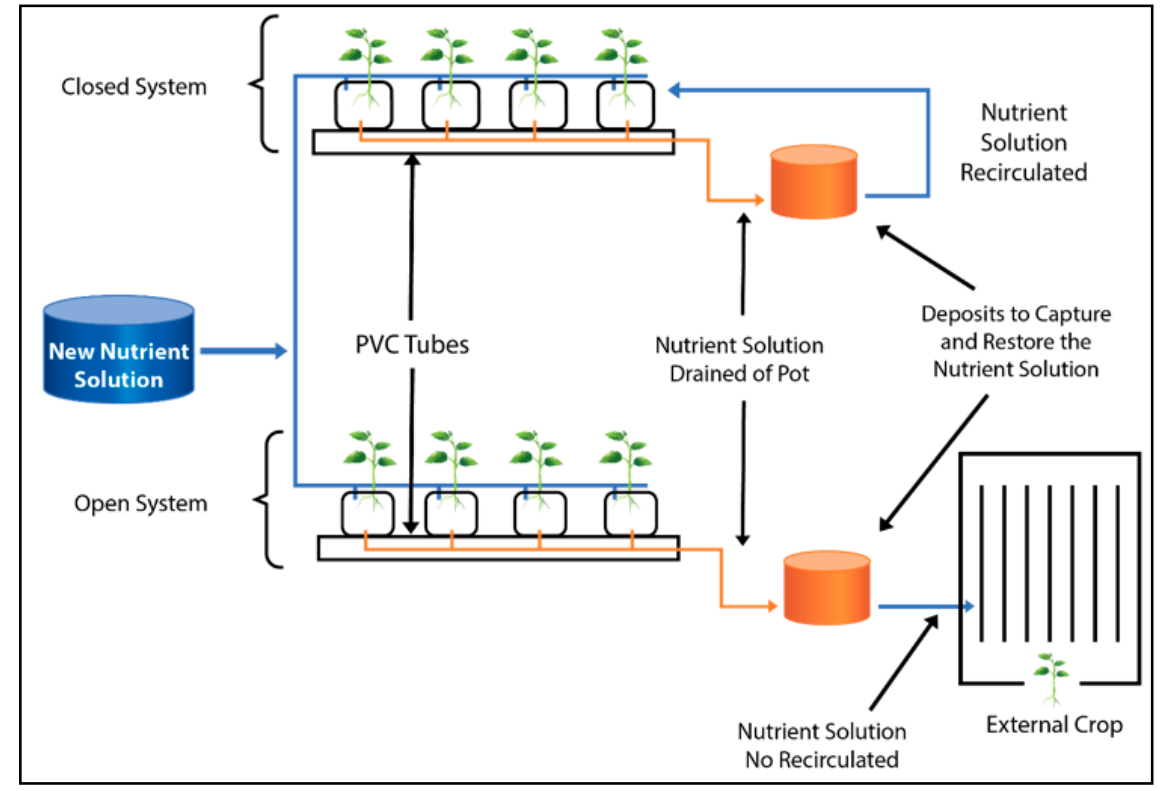

Figure 1. Open and closed hydroponic systems. Mexico, Academic Unit of Agronomy, Autonomous University of Zacatecas, 2017.

higher than those reported in commercial greenhouses with grafted tomato plants (Pardossi et al., 2011). Coincidently, they found no differences in yield between a closed and an open system.

Throughout the tomato harvest, the treatments had no effect on fruit size. The first and second quality grades $(>130 \mathrm{~g}$ and 100-130 g, respectively) were predominant in both treatments with no significant differences (Table 3).

Electric conductivity and $\mathrm{pH}$ of nutrient solution

The $\mathrm{pH}$ value of NS was maintained between 5.5 and 6.0 and EC between 1.8 and $2.3 \mathrm{dS} \mathrm{m}^{-1}$, depending on the crop stage as recommended by Putra $\&$ Yuliando (2015). The changes in these variables were gradual to attenuate the impact in yield of crop.

In drained NS, $\mathrm{pH}$ oscillated between 6.3 and 7.2 , which depended on the ammonium/nitrate ratio. In NS that supply $\mathrm{N}-\mathrm{NH}_{4}^{+}, \mathrm{pH}$ tends to descend, while in those that supply $\mathrm{N}_{-} \mathrm{NO}_{3}{ }^{-}, \mathrm{pH}$ rises (Savvas et al., 2006). The EC of the drained NS increased to values from 3.1 to $5.5 \mathrm{dS} \mathrm{m}^{-1}$, with a mean of 4.49 $\mathrm{dS} \mathrm{m} \mathrm{m}^{-1}$ during the crop cycle. This is because the plant uptakes proportionally more water than nutrients. If we also take into consideration the amount of water lost through evaporation, the drained solution would have a higher concentration of solutes (nutrients) than the water (solvent), thus increasing EC (Dorai et al., 2001).

In conclusion, we did not find differences in yield between the closed and open systems tested. Nonetheless, fertilizers and water use efficiency were higher in the closed system, with concomitant economic and environmental benefits. Since the closed system was more efficient regarding the open system, this makes the former system a good alternative to produce tomato and to preserve the resources involved in the process (like water and fertilizers) and in the environment by reducing pollution.

\section{REFERENCES}

CASIERRA-POSADA, F; AGUILARAVENDAÑO, ÓE. 2008. Calidad en frutos de tomate (Solanum lycopersicum L.) cosechados en diferentes estados de madurez. Agronomía Colombiana 26: 300-307.

COSTA, E; ESPÍRITO SANTO, TL; BATISTA, TB; CARVALHO, TMR. 2018. Diferentes tipos de ambiente protegido e substratos na produção de pimenteiras. Horticultura Brasileira 35: 458-466.

DE LA ROSA-RODRÍGUEZ, R; AVELARMEJÍA, JJ; LARA-HERRERA, A; LOZANOGUTIÉRREZ, J; ESTRADA-CASILLAS, J; CASTAÑEDA-MIRANDA, R. 2017. Agentes fitopatógenos en la solución nutritiva para el cultivo de jitomate en un sistema hidropónico cerrado. Interciencia 42: 236-341.

DE WRACHIEN, D; GOLI, MB. 2015. Global warming effects on irrigation development and crop production: A world-wide view. Agricultural Sciences 6: 734-747.

DORAI, M; PAPADOPOULOS, A; GOSSELIN, A. 2001. Influence of electric conductivity management on greenhouse tomato yield and fruit quality. Agronomie 21: 367-383.

EL-MAGEED, TAA; SEMIDA, WM. 2015. Effect of deficit irrigation and growing seasons on plant water status, fruit yield and water use efficiency of squash under saline soil. Scientia Horticulturae 186: 89-100.

FLORES, J; OJEDA-BUSTAMANTE, W; LÓPEZ, I; ROJANO, A; SALAZAR, I. 2007. Requerimientos de riego para tomate de invernadero. Terra Latinoamericana 25: 127-134.

GREWAL, HS; MAHESHWARI, B; PARKS, SE. 2011. Water and nutrient use efficiency of a low-cost hydroponic greenhouse for a cucumber crop: An Australian case study. Agricultural Water Management 5: 841-846.

HERRERO, B; BLÁZQUEZ, ME; CRISTÓBAL, MD. 2014. Agronomic parameters assessment in hydroponic tomato crop. Horticulura Brasileira 32: 385-390.

KEMPEN, E; AGENBAG, A; DECKERS, S. 2016. Variations in water and macronutrient uptake of soilless tomato as affected by the nutrient solution composition. South African Journal of Plant \& Soil 1: 1-10.

KOMOSA, A; PIROG, ZJW; MARKIEWICZ, B. 2011. Comparison of yield, nutrient solution changes and nutritional status of greenhouse tomato grown in recirculating and non-recirculating nutrient solution systems. Journal Plant Nutrition 34: 1473-1488.

KRAUSE, M; MONACO, P; HADDADE, I; MENEGHELLI, L; SOUZA, T. 2017. Aproveitamento de resíduos agrícolas na composição de substratos para produção de mudas de tomateiro. Horticultura Brasileira 35: 293-298.

KUŞÇU, H; TURHAN, A; DEMIR, AO. 2014. The response of processing tomato to deficit irrigation at various phenological stages in a sub-humid environment. Agricultural Water Management 133: 92-103.

LEWIS, AH; MARMORY, FB. 1940. Nutrient uptake by the tomato plant. Journal of Pomology and Horticultural Science 17: 275-283.

LÓPEZ, PP; CANO, MA; RODRÍGUEZ, RG. 2011. Efecto de diferentes concentraciones de potasio y nitrógeno en la productividad de tomate en cultivo hidropónico. Tecnociencia Chihuahua 5: 98-104.

MAGAÑA-LIRA, N; PEÑA-LOMELÍ, A; SÁNCHEZ-DEL CASTILLO, F; RODRÍGUEZ-PÉREZ, JE; MORENOPÉREZ, EDC. 2013. Comportamiento productivo de híbridos F1 de tomate y sus poblaciones F2. Revista Fitotecnia Mexicana 36: 371-379.

MORENO-PÉREZ, EDC; SÁNCHEZ-DEL CASTILLO, F; GUTIÉRREZ-TLAQUE, J; GONZÁLEZ-MOLINA, L; PINEDAPINEDA, J. 2015. Greenhouse lettuce 
production with and without nutrient solution recycling. Revista Chapingo Serie Horticultura 21: 43-55.

OJODEAGUA, JL; CASTELLANOS, JZ; MUÑOZ, JJ; ALCANTAR, G; TIJERINA, L; VARGAS, P; ENRÍQUEZ, S. 2008. Eficiencia de suelo y tezontle en sistemas de producción de tomate en invernadero. Revista Fitotecnia Mexicana 31: 367-374.

PARDOSSI, A; CARMASSI, G; DIARA, C; INCROCCI, L; MAGGINI, R; MASSA, D. 2011. Fertigation and substrate management in closed soilless culture. Pisa: Departmento di biologia delle painte Agrarie, University of Pisa, (Chapters 1 and 4).

PUTRA, PA; YULIANDO, H. 2015. Soilless culture system to support water use efficiency and product quality: A review. Agriculture and Agricultural Science Procedia 3: 283-288.

SÁNCHEZ-DEL CASTILLO, F; GONZÁLEZMOLINA, L; MORENO-PÉREZ, EDC; PINEDA-PINEDA, J; REYES-GONZALES, CE. 2014. Dinámica nutrimental y rendimiento de pepino cultivado en hidroponía con y sin recirculación de la solución nutritiva. Revista Fitotecnia Mexicana 37: 261-269.
STANGHELLINI, CK; EMPKES, FLK; KNIES, P. 2003. Enhancing environmental quality in agricultural systems. Acta Horticulturae 609: 277-283.

STEINER, AA. 1984. The universal nutrient solution. pp. 633-650. In: Proceedings 6th International Congress on Soilless Culture. Wageningen, The Netherlands.

SAVVAS, D; PASSAM, HC; OLYMPIOS, C; NASI, E; MOUSTAKA, E; MANTZOS, N; BAROUCHAS, P. 2006. Effects of ammonium nitrogen on lettuce grown on pumice in a closed hydroponic system. Horticultural Science 41: 1667-1673. 